\title{
Influence of Beef Cattle Stocking Density on Utilization of Vegetative Communities in a Late-Spring, Early-Summer Native Bunchgrass Prairie
}

\author{
Samuel A. Wyffels (Corresponding author) \\ Northern Agricultural Research Center, Montana State University \\ 3710 Assinniboine Road, Havre, MT 59501, United States \\ Tel: 1-541-805-5792Ｅ-mail: samwyffels@montana.edu \\ Timothy DelCurto \\ Dept. of Animal and Range Sciences, Montana State University \\ PO Box 172900, Bozeman, MT 59717, United States
}

Tel: 1- 406-994-3708Ｅ-mail: timothy.delcurto@ montana.edu

Received: August 3, $2020 \quad$ Accepted: August 26, $2020 \quad$ Published: Sep. 15, 2020

doi:10.5296/jas.v8i4.17462ＵRL: https://doi.org/10.5296/jas.v8i4.17462

\begin{abstract}
This study evaluated the influence of cattle stocking density on the use of botanical communities on a native bunchgrass prairie. In each of two years, 192 cow-calf pairs and 48 yearling heifers were randomly selected for the following grazing treatments: 1) control, no livestock grazing; 2) low stocking, 0.36 animal units (AU) $\cdot$ ha $^{-1}$; 3) moderate stocking, 0.72 $\mathrm{AU} \cdot \mathrm{ha}^{-1}$; and 4) high stocking, $1.08 \mathrm{AU} \cdot \mathrm{ha}^{-1}$ for a 42-day grazing period. Thirty-six monitoring sites were established uniformly along a grid in each paddock. Standing crop and relative preference data for cattle collected from the treatment area were used to develop the following vegetation community classifications: 1) > 20\% introduced; 2) > 40\% native bunchgrass with $>50 \%$ Idaho fescue (Festuca idahoensis); 3) $>40 \%$ native bunch grass with $<50 \%$ Idaho fescue; 4) > 50\% Forb; and 5) other. Utilization for each community type was collected at the end of the grazing period. High stocking density paddocks had higher utilization across all vegetation classifications compared to other stocking densities $(P \leq$ 0.04). Moderate stocking density paddocks were utilized $11.5 \%$ more than low paddocks, however, utilization of introduced vegetative communities, Idaho fescue dominated
\end{abstract}


bunchgrass communities, and forb dominated communities did not differ in use $(P \geq 0.13)$. Use of monitoring to actively adjust stocking densities based on differential community utilization may improve the sustainable grazing of sensitive communities because conventional stocking rate calculations based on total productivity do not account for the selective grazing behavior of cattle.

Keywords: beef cattle, stocking density, plant communities, grazing behavior

\section{Introduction}

Ecological impacts of livestock grazing on public lands is a controversial issue that drives public land use policy in the western United States. Domestic livestock can alter ecosystem processes by altering vegetation composition, reducing the cover of herbaceous plants and litter, disturbing and compacting soils, reducing water infiltration rates, and increasing soil erosion (Belsky and Blumenthal 1997, Milchunas et al. 1998, Krueger et al. 2002). Therefore, grazing plays an influential role in the ecological function of grassland communities, making it imperative for managers to understand grazing behavior and its application to grazing management on rangelands.

In recent years there has been a strong effort to develop grazing systems that promote plant community production, resiliency, as well as livestock production (Walker 1995). Many studies have evaluated different grazing systems and their potential effects on ecological condition as well as animal performance (Walburger et al. 2000, Pavlů et al. 2006, Tracy and Faulkner 2006). Evidence generated from over 60 years of grazing experiments indicates that there is no true superior grazing system (Briske et al. 2008). However, it is generally accepted that selection of the correct stocking rate is the most important of all grazing management decisions in terms of sustainability and profitability (Holechek et al. 2004, Briske et al. 2008). Stocking density is typically set with the objective to balance forage demand of the grazing animals with the annual forage production (Briske et al. 2008). However, this does not consider grazing selectivity and its impacts to vegetative community composition and structure. Effects of stocking density on plant species diversity may have important consequences for grassland community stability and ecosystem function (Hickman et al. 2004). Relative to its impact on plant community structure, diet selection is by far the most important aspect of foraging behavior (Walker 1995). Repeated defoliation can put plants at a competitive disadvantage to non-grazed plants and may result in a reduction in overall plant production and/or overall plant nutritive quality (Fleischner 1994, Walker 1995, Krueger et al. 2002). Due to forage type being a main driver of grazing behavior, it is critical to understand the interaction of grazers and vegetation community utilization within a paddock rather than the utilization of the paddock as a whole. This is not only important for cattle production but also for land management since selective herbivory can have direct and indirect influences on vegetative communities (Riggs et al. 2004). Therefore, the objective of this study was to evaluate the effects of stocking density on vegetation utilization as a function of plant community preference. We hypothesize that beef cattle preference causes variation in plant community use across a range of stocking densities within an allotment pasture. 


\section{Method}

This study was conducted from late-May to early-July for two consecutive years in northeast Oregon at The Nature Conservancy's Zumwalt Prairie Preserve, which is the last large remnant of the Pacific Northwest bunchgrass ecosystem type (Tisdale 1982). The Nature Conservancy's (TNC) Zumwalt Prairie Preserve is located near Enterprise, in northeastern Oregon (lat $45^{\circ} 34^{\prime} \mathrm{N}$, long $122^{\circ} 57^{\prime} \mathrm{W}$ ). The Zumwalt Prairie is situated on a basalt plateau at an elevation of 1340 to $1460-\mathrm{m}$ with a mean slope of $7 \%$. This area receives around $340-\mathrm{mm}$ of precipitation annually, falling in spring and fall as rain, and in winter as snow, with a distinct dry period lasting from July through August. The average annual temperature is $6.7^{\circ} \mathrm{C}$, and ranges from $-3.8^{\circ} \mathrm{C}$ in December to $17.5^{\circ} \mathrm{C}$ in July. Soils are mostly shallow to moderately deep silt loams with localized areas of shallow and very shallow rocky soils (Schmalz et al. 2013). Vegetation is dominated by native bunchgrass species (45\% of total vegetation by weight) that include Idaho fescue (Festuca idahoensis), prairie Junegrass (Koeleria macrantha), and bluebunch wheatgrass (Pseudoroegneria spicata) with the main forbs species (44\% of total vegetation by weight) consisting of prairie smoke (Geum triflorum), twin arnica (Arnica sororia) and lupine (Lupinus spp.). Shrub species constitute a small fraction $(<2 \%)$ of the total vegetation and consist primarily of snowberry (Symphoricarpos albus) and wild rose (Rosa spp.). Total mean annual production for vegetation across the study area ranges from 1000 to $1200 \mathrm{~kg} \cdot \mathrm{ha}^{-1}$. The Zumwalt Prairie has been grazed by livestock since Native Americans living in the area acquired horses in the early 18th century. These productive grasslands also attracted Euro-American settlers in the late 19th century and the area has been used as spring/summer pastureland for livestock since that time (Bartuszevige et al. 2012). Although the Zumwalt Prairie is referred to as native grassland, Euro-American settlers seeded nonnative grasses to increase forage for livestock and to rehabilitate overgrazed areas to minimize erosion. Nonnative grasses encompass approximately $11 \%$ of the total available vegetation and are composed primarily of Kentucky bluegrass (Poa pratensis), brome species (Bromus spp.), timothy (Phleum pratense) and intermediate wheatgrass (Thinopyrum intermedium).

Our study was conducted as a randomized complete block design with four grazing treatments. The total study area consisted of 640-ha that was fenced into four 160-ha blocks each containing four 40-ha paddocks. In each of the two years, 192 cow-calf pairs $(549.27 \mathrm{~kg}$, body condition score $[\mathrm{BCS}]=4.89)$ and 48 yearling heifers $(383.34 \mathrm{~kg}, \mathrm{BCS}=5.02)$ were stratified by age and body condition, and randomly allotted to the following stocking density treatments: 1) control, no livestock grazing; 2) low stocking, 0.36 animal units (AU) $\cdot \mathrm{ha}^{-1} ; 3$ ) moderate stocking, $0.72 \mathrm{AU} \cdot \mathrm{ha}^{-1}$; and 4) high stocking, $1.08 \mathrm{AU} \cdot \mathrm{ha}^{-1}$ for a 42-day grazing period. Stocking density was derived by setting the prevailing stocking rate used by area producers as moderate ( $30-40 \%$ use, depending on year), which is consistent with long-term grazing studies on bunchgrass rangelands in the intermountain west (Holechek et al. 2004). Low was then set at $50 \%$ of the moderate stocking density and high was set as $150 \%$ of the moderate stocking density.

Within each paddock, 36 vegetation sampling sites were established uniformly along a grid of 6 north to south and 6 east to west transects (Figure 1). Standing crop by species was 


\section{Macrothink}

Journal of Agricultural Studies

ISSN 2166-0379

2020, Vol. 8, No. 4

collected in late-spring to early-summer prior to initiation of grazing treatments (Table 1). Half meter square quadrats ( $n=36$ per experimental unit) were placed at each of the monitoring points approximately every 90 meters along each transect to measure standing crop by species. Standing crop by species was then collected by clipping each quadrat and separating clipped vegetation by species and placing them in a paper bag. Samples were dried in a forced air oven at $55^{\circ} \mathrm{C}$ then weighed and recorded giving the percent standing crop by species on a dry matter basis. Standing crop was then used to develop criteria for vegetation community classification. Vegetation communities were classified as follows: 1) > 20\% introduced; 2) > 40\% native bunchgrass with $>50 \%$ Idaho fescue; 3) > 40\% native bunch grass with $<50 \%$ Idaho fescue; 4) $>50 \%$ Forb; and 5) other. Idaho fescue was used as a key species for breaking out native bunchgrass communities due to its prevalence, its importance to ecological function and its relative preference by cattle (Hormay 1956, Wyffels 2009).

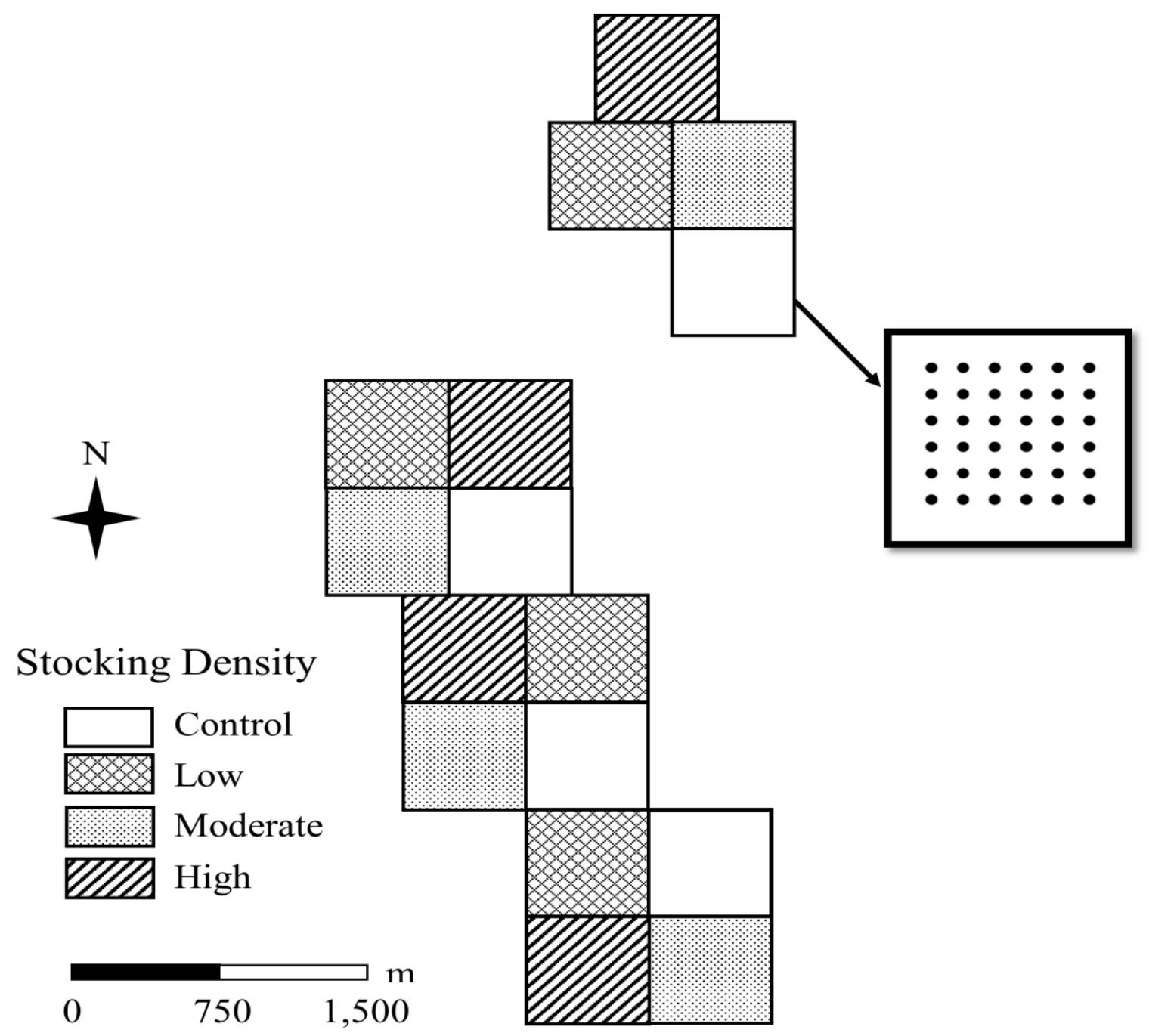

Figure 1. Layout of the study paddocks, illustrating the randomized complete block design with four 40-ha replicates of four stocking densities and view of the 36 subplots in each paddock where standing crop and utilization were sampled on the Zumwalt Prairie, northeast Oregon 
Table 1. Production by forage class and most prevalent vegetative species making up the botanical composition of treatment pastures on The Nature Conservancy's Zumwalt Prairie Preserve

\begin{tabular}{|c|c|c|c|c|}
\hline \multirow[b]{2}{*}{ Production $\left(\mathbf{k g} \cdot \mathbf{h a}^{-1}\right)$} & \multicolumn{4}{|c|}{ Stocking Density } \\
\hline & Control & Low & Moderate & High \\
\hline Grass & 611.58 & 610.07 & 670.79 & $\mathbf{5 7 1 . 1 1}$ \\
\hline Idaho Fescue (Festuca idahoensis) & 245.54 & 183.58 & 162.41 & 191.13 \\
\hline Bluebunch Wheatgrass (Pseudoroegneria spicata) & 138.34 & 185.76 & 134.36 & 129.41 \\
\hline Kentucky Bluegrass (Poa pratensis) & 65.08 & 68.87 & 125.93 & 92.46 \\
\hline Prairie Junegrass (Koeleria macrantha) & 47.41 & 41.61 & 53.01 & 59.25 \\
\hline Smooth Brome (Bromus inermis) & 16.34 & 3.09 & 25.80 & 10.33 \\
\hline Timothy (Phleum pratense) & 1.80 & 9.15 & 21.56 & 12.61 \\
\hline Sandberg Bluegrass (Poa secunda) & 7.93 & 10.33 & 13.53 & 8.35 \\
\hline California Needlegrass (Achnatherum occidentale) & 2.44 & 6.33 & 15.88 & 4.36 \\
\hline Grass-Like & 5.93 & 8.49 & 18.08 & 15.09 \\
\hline Colorado Rush (Juncus confusus) & 0.94 & 5.57 & 6.63 & 5.75 \\
\hline Dunhead Sedge (Carex phaeocephala) & 1.46 & 0.04 & 2.43 & 4.06 \\
\hline Forbs & 551.39 & 410.16 & 490.30 & 552.73 \\
\hline Prairie Smoke (Geum triflorum) & 137.53 & 63.01 & 125.01 & 117.33 \\
\hline Silky Lupine (Lupinus sericeus) & 75.55 & 59.74 & 55.71 & 76.87 \\
\hline Slender Cinquefoil (Potentilla gracilis) & 34.23 & 56.43 & 39.36 & 66.37 \\
\hline Hoary Balsamroot (Balsamorhiza incana) & 36.72 & 33.91 & 18.96 & 37.22 \\
\hline Twin Arnica (Arnica sororia) & 32.99 & 19.02 & 11.65 & 28.01 \\
\hline Western Yarrow (Achillea millefolium) & 27.85 & 15.56 & 25.08 & 22.97 \\
\hline Shrubs & 0.98 & 0.87 & 1.03 & 0.19 \\
\hline Dwarf Rose (Rosa gymnocarpa) & 0.13 & 0.36 & 0.69 & 0.00 \\
\hline Nootka Rose (Rosa nutkana) & 0.74 & 0.11 & 0.11 & 0.08 \\
\hline Total Production & 1169.87 & 1029.59 & 1180.19 & 1139.12 \\
\hline
\end{tabular}

Post treatment utilization estimates were obtained by means of ocular estimates similar to that described by Parsons et al. (2003). Observers were trained to recognize and assign one of the following five utilization classes to each sampling site: 1) $0 \%$ use, 2) $1-25 \%$ use, 3) $26-$ $50 \%$ use, 4) $51-75 \%$ use and 5) $76-100 \%$ use. Prior to collecting utilization data, each observer estimated the utilization of ten $0.25-\mathrm{m}^{2}$ plots that had previously been clipped to simulate different levels of use. When finished, the remaining vegetation was clipped to 
within 2-cm of ground level and weighed to determine actual utilization values. The estimated utilization values were then correlated to the actual utilization values to develop a regression equation for each observer, which was then used to correct for observer biases. Utilization estimates were taken at each of the sampling sites in every paddock after the 42-day grazing trial for each year.

Utilization data were analyzed using the GLM procedures of SAS (2002) corresponding to a randomized block design including grazing treatment, vegetation classification, year, and their interactions as fixed effects. Paddock was considered the experimental unit and treatment $\times$ block was the specified error term. Differences were considered significant at $P \leq$ 0.05 and tendencies were considered at $P \leq 0.10$.

\section{Results}

Paddock level utilization increased $10-14 \%$ as stocking density increased (Figure 2). Control, non-grazed, paddocks did not differ in utilization across vegetation classifications $(P$ $\geq 0.49$; Figure 3 ) with an overall utilization of $9.52 \pm 1.07 \%$. Herbivory in the control paddocks are attributed to native herbivores, small mammals, and/or insects. In the low stocking density paddocks, introduced vegetative communities were utilized higher than all other vegetation classes $(P<0.01$; Figure 3$)$. All other vegetation communities showed no difference in levels of utilization at low stocking densities $(P \geq 0.27)$. In the moderate stocking density paddocks, introduced vegetative communities were grazed at higher levels than all other communities ( $P \leq 0.04$; Figure 3 ). Additionally, bunchgrass and forb communities showed no difference in levels of utilization $(P \geq 0.12)$ with a tendency for non-classified vegetative communities being utilized at higher levels than Idaho fescue dominated bunchgrass communities at moderate stocking $(P=0.08)$. Non-classified vegetative communities were also utilized at higher levels than forb dominated communities at moderate stocking densities $(P=0.02)$. High stocking density paddocks had higher utilization rates in the introduced vegetative communities than Idaho fescue dominated bunchgrass communities, forb dominated communities, and non-classified vegetative communities $(P \leq 0.01)$. Additionally, introduced vegetative communities tended to be grazed higher than bunchgrass communities lacking Idaho fescue at high stocking densities $(P=$ 0.07; Figure 3). Bunchgrass communities lacking in Idaho fescue had higher utilization values than Idaho fescue dominated bunchgrass communities in the high stocking density paddocks $(P=0.02)$. 


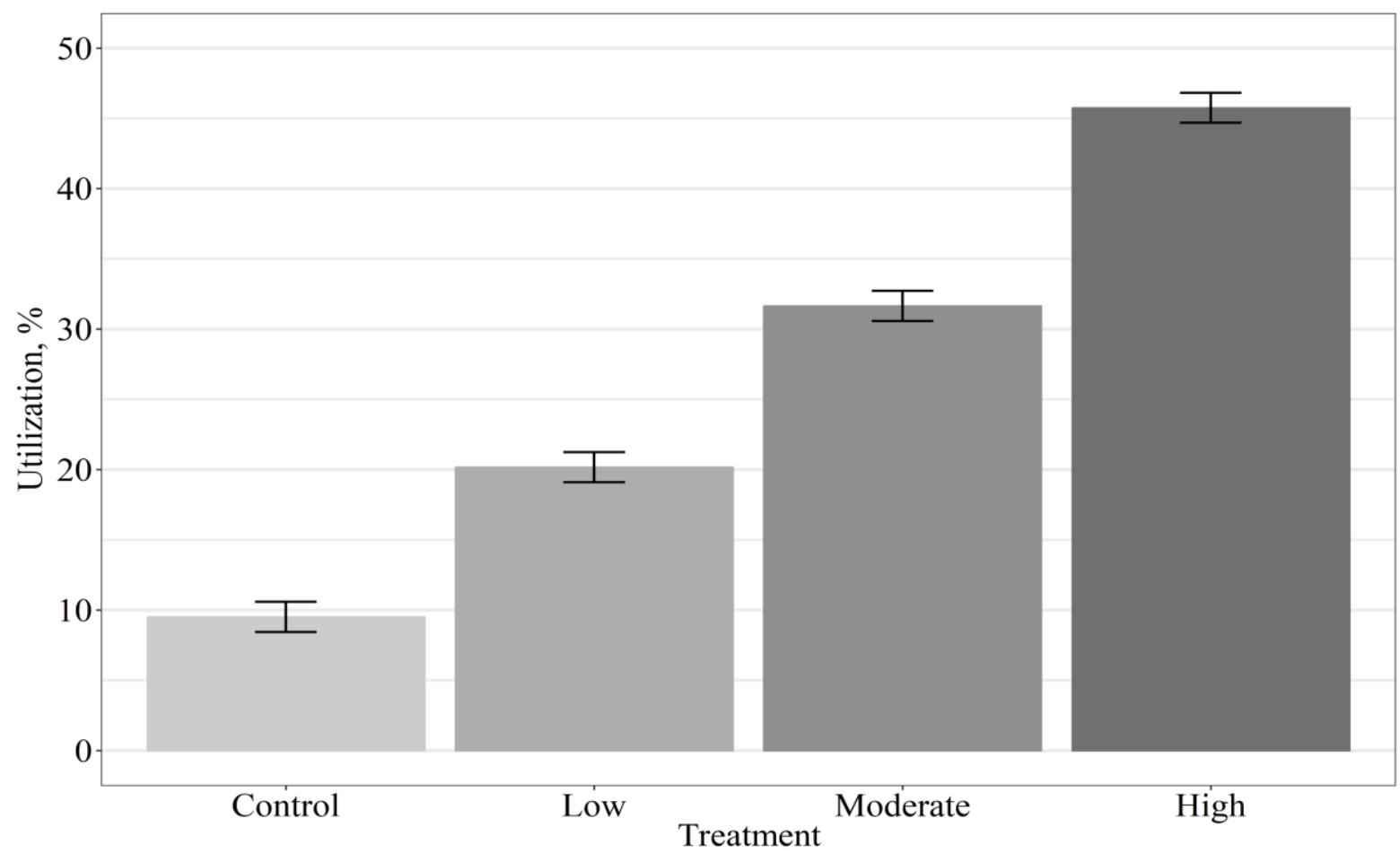

Figure 2. Paddock level utilization (\%) by cattle grazing at stocking densities of control (no grazing), low (0.36 AU $\left.\cdot \mathrm{ha}^{-1}\right)$, moderate $\left(0.72 \mathrm{AU} \cdot \mathrm{ha}^{-1}\right)$, and high $\left(1.08 \mathrm{AU} \mathrm{ha}^{-1}\right)$ for a 42-day grazing period on the Zumwalt Prairie, northeast Oregon

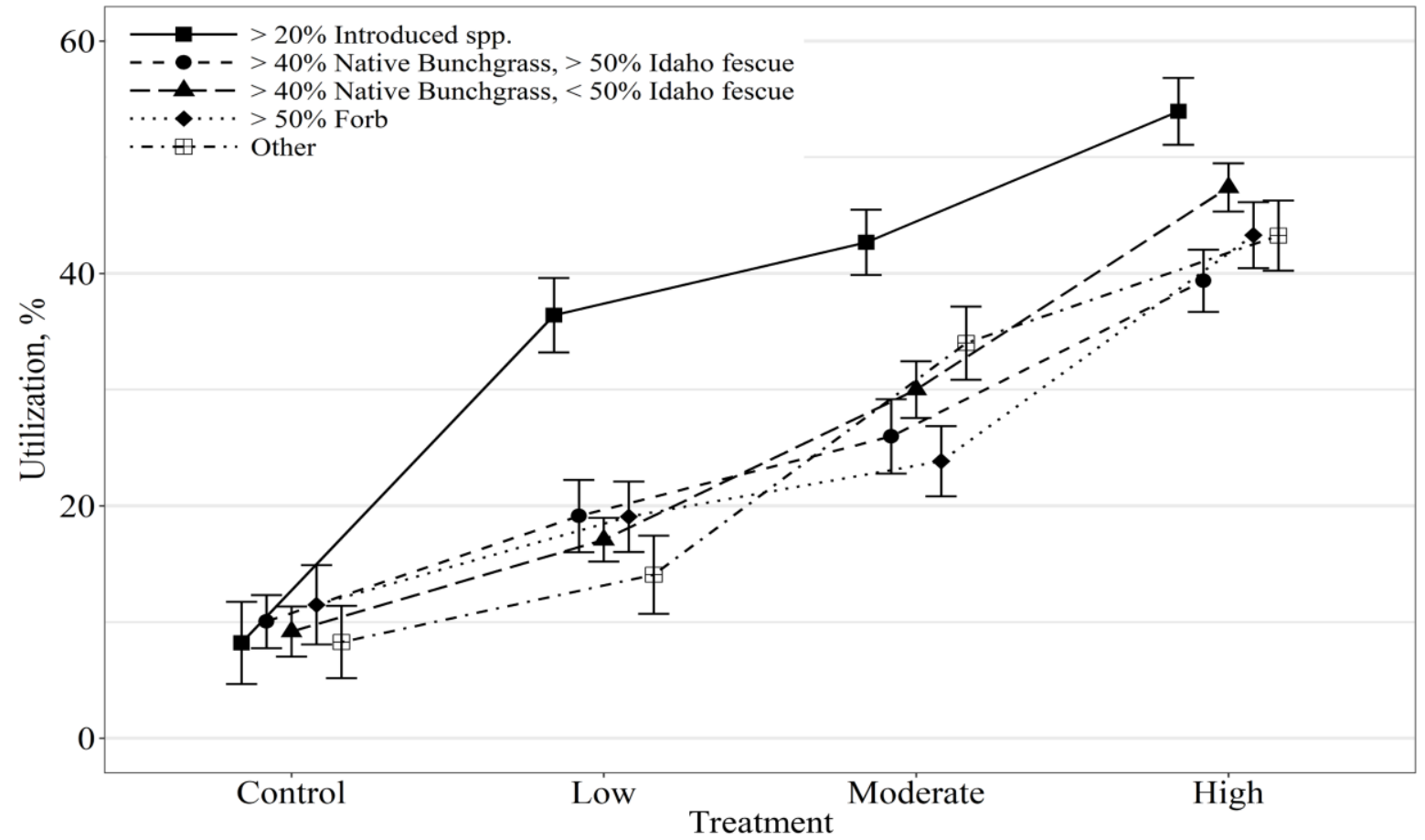

Figure 3. Vegetation community utilization by cattle grazing at stocking densities of control (no grazing), low $\left(0.36 \mathrm{AU} \cdot \mathrm{ha}^{-1}\right)$, moderate $\left(0.72 \mathrm{AU} \cdot \mathrm{ha}^{-1}\right)$, and high $\left(1.08 \mathrm{AU} \cdot \mathrm{ha}^{-1}\right)$ for a 42-day grazing period on the Zumwalt Prairie, northeast Oregon 
High stocking density paddocks had higher utilization values across all vegetation classifications compared to other stocking densities $(P \leq 0.04$; Figure 3). Overall, moderate stocking density paddocks were utilized $11.5 \%$ more than low paddocks. However, utilization of introduced vegetative communities, Idaho fescue dominated bunchgrass communities and forb dominated communities did not differ between low and moderate stocking densities $(P \geq$ 0.13; Figure 3). Bunchgrass communities lacking in Idaho fescue and non-classified vegetative communities had higher utilization in the moderate stocking density compared to the low $(P<0.01)$. There were no differences in forb dominated and non-classified communities between control and low stocking densities $(P \geq 0.11$; Figure 3$)$.

\section{Discussion}

Sustainable grazing management often targets 50\% utilization which applies well in the southern pine forest, humid grasslands, and annual grasslands, but can result in rangeland deterioration in the semiarid grasslands, desert, and coniferous forest rangelands (Holechek et al. 2004). Therefore, a conservative stocking density is encouraged for semiarid grasslands involving 35\% use of forage; to optimize ranching risk, financial returns and vegetation and livestock productivity (Holechek et al. 1999). Selectivity by herbivores may be influenced by the presence of inter-and intraspecific competition among animals in an area by changing the short-term relative availability of the different plant species (Vallentine 1990, Damiran et al. 2019). Therefore, changes in dietary preferences in response to increasing stocking density are a function of both plant palatability and availability. As the availability of preferred plants decreases, the search time required for consumption may not be effective and alternative species are utilized instead (Vallentine 1990, Wyffels 2009, Clark et al. 2013). This suggests that as preferred species become more difficult to find at higher stocking densities, cattle may consume higher amounts of abundant species, such as bunchgrasses and forbs. However, even though utilization of non-preferred communities increased with increased stocking density in our study, preferred communities had the greatest utilization across all stocking densities. Other research has shown similar results, where cattle grazing late season grand fir habitat types had a strong preference for grasses regardless of stocking rate, however, as stocking rate increased grass consumption decreased and shrub consumption increased (Clark et al. 2013). These subtle shifts in diet preference with increased stocking rates suggest that there are forage quantity thresholds where animals alter diet selection and, in turn, plant community use when availability of preferred vegetation becomes limited.

Early homesteaders often planted rangelands with non-native grasses (e.g, smooth brome [Bromus inermis], intermediate wheatgrass [Thinopyrum intermedium], and timothy [Phleum pretense]), to enhance forage production (Kennedy et al. 2009). These non-native grasses represent $11 \%$ of the botanical composition of the Zumwalt Prairie, of which, Kentucky bluegrass accounts for $7.8 \%$, brome spp. $1.7 \%$, timothy $1 \%$, and intermediate wheatgrass 0.5\% (Wyffels 2009; Table 1). Difference in utilization for native and non-native vegetation communities was most pronounced in the low and moderate stocking densities. Only at the high stocking densities (150\% of traditional use) did utilization patterns begin to converge among plant communities. Our results are consistent with other research that observed similar plant community use patterns, where cattle had higher use of plant communities comprised of 
non-native grasses (Cruz and Ganskopp 1998, Clark et al. 2013). Thus, the presence of non-native vegetation may reduce utilization of native bunchgrass communities during the growing season. As a result, non-native forage species in extensive bunchgrass rangelands may provide an ecological benefit to native bunchgrasses that are not highly tolerant of grazing during the growing season at low to moderate stocking densities.

Plant community characteristics are important factors of grazing behavior and critical to understanding the interaction of grazers and plant community dynamics. Selective herbivory can have direct and indirect influences on the structure and composition of vegetative communities (Riggs et al. 2004). Without an in depth understanding of the interaction between grazing herbivores and the grazed plant communities, it will be difficult to assess how shifts in driving factors might impact vegetation dynamics (Svejcar et al. 2014). Therefore, understanding the relationship between livestock grazing behavior and vegetation use is not only important for cattle production but also for the sustainability of land management on agroecosystem process and function.

\section{Acknowledgments}

This research was funded by the United States Department of Agriculture National Research Initiative Grants Program, the Eastern Oregon Agricultural Research Center of Oregon State University, and The Nature Conservancy.

\section{References}

Bartuszevige, A. M., Kennedy, P. L., \& Taylor. R. V. (2012). Sixty-seven years of landscape change in the last, large remnant of the Pacific Northwest bunchgrass prairie. Natural Areas Journal, 32, 166-170. https://doi.org/10.3375/043.032.0205

Belsky A. J., \& Blumenthal, D. M. (1997). Effects of livestock grazing on stand dynamics and soils in upland forests of the interior West. Conservation Biology, 11(2), 315-27. https://doi.org/10.1046/j.1523-1739.1997.95405.x

Briske, D. D., Derner, J., Brown, J., Fuhlendorf, S. D., Teague, W., Havstad, K., ... Willms, W. (2008). Rotational grazing on rangelands: reconciliation of perception and experimental evidence. Rangeland Ecology \& Management, 61, 3-17. https://doi.org/10.2111/06-159R.1

Clark, A., DelCurto, T., Vavra, M., \& Dick, B. L. (2013). Stocking rate and fuels reduction effects on beef cattle diet composition and quality. Rangeland Ecology \& Management 66, 714-720. https://doi.org/10.2111/REM-D-12-00122.1

Cruz, R., \& Ganskopp, D. (1998). Seasonal preferences of steers for prominent northern Great Basin grasses. Journal of Range Management, 51, 557-565. https://doi.org/10.2307/4003376

Damiran, D., DelCurto, T., Findholt, S. L., Johnson, B. K., \& Vavra, M. (2019). The effects of previous grazing on the subsequent nutrient supply of ungulates grazing late-summer mixed-conifer Rangelands. Sustainable Agriculture Research, 8, 13-27. https://doi.org/10.22004/ag.econ.301906 
Fleischner, T. L. (1994). Ecological costs of livestock grazing in western North America. Conservation Biology, 8, 629-644. https://doi.org/10.1046/j.1523-1739.1994.08030629.x

Hickman, K. R., Hartnett, D. C., Cochran, R. C., \& Owensby, C. E. (2004). Grazing management effects on plant species diversity in tallgrass prairie. Journal of Range Management, 57, 58-65.

https://doi.org/10.2111/1551-5028(2004)057[0058:GMEOPS]2.0.CO;2

Holechek, J. L., Gomez, H., Molinar, F., \& Galt, D. (1999). Grazing studies: what we've learned. Rangelands, 28, 12-16. https://doi.org/10.2458/azu_rangelands_v28i1_holechek

Holechek, J. L., Pieper, R. D., \& Herbel, C. H. (2004). Range management: Principles and practices. 5th edition. Chapter 8: Considerations concerning stocking rate. 216-254. Pearson Prentice Hall, New Jersey.

Hormay, A. L. (1956). How livestock grazing habits and growth requirements of range plants determine sound grazing management. Journal of Range Management, 9, 161-164. https://doi.org/10.2307/3894382

Kennedy, P. L., DeBano, S. J., Bartuszevige, A. M., \& Lueders, A. S. (2009). Effects of native and non-native grassland plant communities on breeding passerine birds: Implications for restoration of northwest bunchgrass prairie. Restoration Ecology, 17, 515-525. https://doi.org/10.1111/j.1526-100X.2008.00402.x

Krueger, W. C., Sanderson, M. A., Cropper, J. B., Miller-Goodman, M., Kelley, C.E., Pieper, R.D., ...Trlica, M. J. (2002). Environmental impacts of livestock grazing on U.S. grazing lands. Council for Agricultural Science and Technology Issue Paper. V.22

Milchunas, D., Lauenroth, W., \& Burke, I. (1998). Livestock grazing: animal and plant biodiversity of shortgrass steppe and the relationship to ecosystem function. OIKOS, 83, 65-74. https://doi.org/10.2307/3546547

Parsons, C. T., Momont, P. A., Delcurto, T., McInnis, M., \& Porath, M. L. (2003). Cattle distribution patterns and vegetation use in mountain riparian areas. Journal of Range Management, 56, 334-341. https://doi.org/10.2458/azu_jrm_v56i4_parsons

Pavlů, V., Hejcman, M., Pavlů, L., Gaisler, J., \& Nežerková, P. (2006). Effect of continuous grazing on forage quality, quantity and animal performance. Agriculture, Ecosystems \& Environment, 113, 349-355. https://doi.org/10.1016/j.agee.2005.10.010

Riggs, R. A., Cook, J. G., \& Irwin, L. L. (2004). Management implications of ungulate herbivory in Northwest forest ecosystems. In: Transactions of the North American Wildlife and Natural Resource Conference. 16-20 March 2004; Spokane, WA, USA., 69, 759-784.

SAS. (2002). SAS/STAT guide for personal computer. Version 9.3. SAS Institute: Cary, NC.

Schmalz, H. J., Taylor, R. V., Johnson, T. N., Kennedy, P. L., DeBano, S. J., Newingham, P. A. \& McDaniel, B. A. (2013). Soil morphologic properties and cattle stocking rate affect dynamic soil properties. Rangeland Ecology \& Management, 66, 445-453. 
https://doi.org/10.2111/REM-D-12-00040.1

Svejcar, T., James, J., Hardegree, S., \& Sheley, R. (2014). Incorporating plant mortality and recruitment into rangeland management and assessment. Rangeland Ecology \& Management, 67, 603-613. https://doi.org/10.2111/REM-D-13-00102.1

Tisdale, E. W. (1982). Grasslands of western North America: The Pacific Northwest Bunchgrass. P. 232-245 in A. C. Nicholson, A. McLean, T. E. Baker, editors. Grassland ecology and classification (symposium proceedings). British Columbia Ministry of Forests, Kamloops, British Columbia, Canada.

Tracy, B. F., \& Faulkner, D. B. (2006). Pasture and cattle responses in rotationally stocked grazing systems sown with differing levels of species richness. Crop Science, 46, 2062-2068. https://doi.org/10.2135/cropsci2005.12.0473

Vallentine, J. F. (1990). Grazing Management. Academic Press Inc California. p 178-184.

Walburger, K., DelCurto, T., Vavra, M., Bryant, L., \& Kie, J. G. (2000). Influence of a grazing system and aspect, north vs. south, on the nutritional quality of forages, and performance and distribution of cattle grazing forested rangelands. Proceedings of Western Section, American Society of Animal Sciences, 181-184.

Walker, J. W. (1995). Viewpoint: grazing management and research now and in the next millennium. Journal of Range Management, 48, 350-357. https://doi.org/10.2307/4002488

Wyffels, S. A. (2009). Influence of stocking density on grazing beef cattle performance, diet composition, foraging efficiency, and diet quality on a late-spring early-summer native bunchgrass prairie [thesis]. Corvallis, OR, USA: Oregon State University.

\section{Copyright Disclaimer}

Copyright for this article is retained by the author(s), with first publication rights granted to the journal.

This is an open-access article distributed under the terms and conditions of the Creative Commons Attribution license (http://creativecommons.org/licenses/by/4.0/). 